\title{
PENGARUH EDUCATIONAL DAN ECONOMIC EMPOWERMENT TERHADAP NEW VENTURE CREATION: PERAN MODERASI ENTREPRENEURIAL SELF- EFFICACY
}

\author{
Noormalita Primandaru \\ STIE YKPN \\ noormalita@stieykpn.ac.id
}

\begin{abstract}
The current condition of women in the Bantul Coast has low knowledge, skills, creative attitudes, and aspirations, which results in many women living in poverty. Therefore, women on the coast need to be empowered. Women's empowerment that needs to be done is empowerment in the economic field which is useful for overcoming poverty and education that is useful for developing organizational skills. This study aims to examine the effect of educational empowerment and economic empowerment on new venture creation and entrepreneurial self-efficacy as moderating variables in women on the Bantul coast. The sample in this study are women who are members of the Family Welfare Development (PKK) group in the coastal village of Bantul. The analytical model used is the Partial Least Square (PLS). The results of this study are the first effect of economic empowerment on new venture creation, the second is the effect of educational empowerment on new venture creation, and the third is entrepreneurial self-efficacy moderating the effect of education empowerment and economic empowerment on new venture creation. The managerial implication in this research is support from the government, universities, private institutions, and the community regarding improving the quality of women's HR strategies, such as insight, knowledge, and skills training, improvement, and development of productive economic activities increasing access to economic resources, such as capital. and information technology, strengthen and develop microeconomic institutions, and develop mutually beneficial business partnerships.
\end{abstract}

Keywords: empowerment; educational; economic; self-efficacy; new venture creation.

\section{PENDAHULUAN}

Wilayah pesisir memiliki permasalahan kompleks yang disebabkan oleh konflik kebijakan, perilaku manusia dan kondisi alam yang terus berubah. Permasalahan tersebut berdampak terhadap kondisi sosial ekonomi masyarakat pesisir, utamanya adalah munculnya masalah kemiskinan. Kemiskinan masyarakat pesisir merupakan sesuatu yang sangat ironi karena masyarakat hidup di tengah kekayaan sumberdaya alam yang melimpah (BAZNAS, 2019). Menurut Mulyadi (2005), empat masalah pokok yang menjadi penyebab kemiskinan, yaitu kurangnya kesempatan (lack of opportunity), rendahnya kemampuan (low of capabilities), kurangnya jaminan (low level-security), dan keterbatasan hak-hak sosial, ekonomi dan politik sehingga menyebabkan kerentanan (vulnerability), keterpurukan (voicelesness), dan ketidakberdayaan (powerless) dalam segala bidang.

Dalam program pengentasan kemiskinan, biasanya pemerintah atau kelompok masyarakat menfokuskan hanya pada keluarga dan kurang memperhatikan peran perempuan. Padahal perempuan dalam struktur kemiskinan menjadi salah satu individu yang rentan mengalami dampak negatif kemiskinan. Banyak perempuan mengalami strees karena himpitan ekonomi, yang secara psikologis sifat feminitasnya perempuan merasa harus memenuhi semua kehendak domestik keluarga mulai dari suami hingga anak-anak. Hal tersebut disebabkan ketakberdayaan, bahkan ada perempuan yang bunuh diri karena faktor kemiskinan tersebut (Lestari, 2014). Pemberdayaan sebagai proses pengembangan berdasarkan partisipasi kelompok agar individu dan kelompok yang terpinggirkan memperoleh kendali yang lebih besar atas kehidupan dan lingkungan mereka, memperoleh sumber daya dan hak dasar,mampu meraih tujuan hidupnya, serta agar marginalisasi masyarakat berkurang (Maton, 2008). Dalam praktiknya, kegiatan pemberdayaan perempuan berarti perempuan memiliki kesempatan untuk memperbaiki dan meningkatkan kondisi ekonominya (Palaon \& Dewi, 2019) 
Kabupaten Bantul merupakan salah satu kabupaten yang berada di Daerah Istimewa Yogyakarta, memiliki beragam potensi perekonomian mulai dari pertanian, perikanan dan peternakan, hutan, flora dan fauna, dan potensi wisata yang cukup luas. Kabupaten Bantul dimanfaatkan sebagai destinasi wisata nasional dan internasional yang dikelola oleh dinas terkait. Akan tetapi menurut Tim Koordinasi Penanggulangan Kemiskinan (TKPK), Kabupaten Bantul tercatat pada 2018 yaitu 40\% dari jumlah seluruh penduduk wilayah kabupaten Bantul dari total penduduk kabupaten Bantul tahun 2018 sebesar 94.037 jiwa, termasuk rumah tangga dengan kondisi sosial ekonomi terbawah secara nasional (tkpk.bantulkab.go.id, 2018).

Dilihat dari kondisi wilayah pesisir Bantul, perlu adanya perubahan daya pikir masyarakat dalam peningkatan kesejahteraan terlebih khususnya perempuan. Kondisi perempuan di Pesisir Bantul saat ini adalah rendahnya pengetahuan, keterampilan, sikap kreatif dan aspirasi, yang mengakibatkan banyak perempuan hidup dalam kemiskinan dan termarginalkan. Oleh sebab, itu perempuan perlu diberdayakan. Pemberdayaan perempuan yang perlu dilakukan adalah pemberdayaan dalam bidang ekonomi yang berguna untuk mengatasi kemiskinan dan pendidikan yang berguna untuk mengembangkan kemampuan dalam pengorganisasian (Hasanah, 2013).

Pemberdayaan dalam bidang ekonomi, yang dapat dilakukan adalah seperti bantuan modal usaha, bantuan simpan pinjam, membuat koperasi, dan lain sebagainya (Muzdalifah, 2013). Sedangkan pemberdayaan pendidikan yaitu dengan adanya keterampilan teknis, strategi komunikasi pemasaran, dan penggunaan internet (Ganiem, 2017). Salah satu sektor yang dapat diberdayakan sebagai cara untuk meningkatkan kemampuan ekonomi perempuan yaitu dengan adanya pemberdayaan UKM. Melalui UMKM dapat mendorong produktivitas dan kemandirian ekonomi keluarga. Hal ini menjelaskan bahwa perempuan juga merupakan pendorong pertumbuhan ekonomi dan juga memiliki dampak sosial yang positif bagi perempuan itu sendiri serta lingkungan sosial masyarakat (Palaon \& Dewi, 2019). Sedangkan Segal et.al. (1995) menyatakan bahwa untuk memberdayakan potensi seseorang dalam menciptakan sebuah usaha yang baru, perlu adanya entrepreneurial self-efficacy yang dipengaruhi oleh pengalaman sosial, prestasi kerja, dan pengalaman.

Kewirausahaan perempuan berkontribusi terhadap stabilitas, kesejahteraan masyarakat, dan memberikan peluang ekonomi bagi kelompok yang kurang beruntung (Sarah \& Lubem, 2018). Menurut Veheul et al. (2005), meningkatnya minat dalam kewirausahaan perempuan disebabkan oleh fakta bahwa wirausaha perempuan sekarang dianggap sebagai kekuatan penting dalam pembangunan ekonomi negara dan di negara berkembang, keterlibatan perempuan dalam usaha kecil memungkinkan mereka untuk meningkatkan kehidupan mereka dan orang-orang dari banyak lainnya dengan menciptakan lapangan kerja baru (Kirk \& Belovies, 2006). Menurut Supeni \& Sari (2011), untuk meningkatkan kesejahteraan ekonomi perempuan adalah dengan menggunakan model pengembangan manajemen usaha kecil. Hal tersebut akan membantu para perempuan untuk mendapatkan akses ke sumber-sumber ekonomi, untuk mencapai posisi yang sama, untuk memiliki pasar, keuangan dan keterampilan bisnis untuk meningkatkan pertumbuhan bisnis mereka sendiri. Selanjutnya penelitian yang sama dibahas oleh Ahlin et al. (2013) menyatakan bahwa logika teoritis kognitif sosial dan teori inovasi untuk mengembangkan model konseptual kreativitas wirausahawan, entrepreneurial self-efficacy, dan hasil inovasi. Temuan empiris mendukung sebagian yang diusulkan efek moderasi dari entrepreneurial self-efficacy, tetapi dengan variasi yang sama antar negara.

Berdasarkan latar belakang yang telah dipaparkan di atas, penelitian ini difokuskan untuk mengetahui pengaruh pengaruh education empowerment dan economic empowerment, terhadap new venture creation dan entrepreneurial self-efficacy sebagai variabel pemoderasi pada perempuan di wilayah pesisir Bantul. Hasil penelitian ini diharapkan dapat digunakan untuk menjadi masukan kepada pemerintah mengenai pemberdayaan perempuan di wilayah pesisir dalam rangka mendorong kemajuan dan kesejahteraan ekonomi masyarakat. Secara lebih detail tujuan yang ingin dicapai dari penelitian ini adalah (1) menganalisis pengaruh entrepreneurial education yang dimoderasi oleh entrepreneurial self-efficacy pada new venture creation perempuan di wilayah pesisir Bantul, (2) menganalisis pengaruh economic empowerment terhadap yang dimoderasi oleh entrepreneurial selfefficacy pada new venture creation. 


\section{KAJIAN PUSTAKA DAN PENGEMBANGAN HIPOTESIS}

\section{Pemberdayaan Perempuan}

Teori pemberdayaan mengusulkan strategi untuk mengurangi marjinalisasi dan ketidakadilan di masyarakat. Hal ini menuntut pengembangan kapasitas, membangun kesadaran dan pengembangan keterampilan untuk meningkatkan status kaum yang terpinggirkan (Lubem \& Sarah, 2018). Pemberdayaan perempuan merupakan suatu upaya untuk meningkatkan kemampuan perempuan dalam memperoleh akses dan kontrol terhadap sumberdaya dalam aspek kehidupan (Kemensos, 2011). Supeni \& Sari (2011) menyatakan bahwa terdapat lima unsur utama yang perlu diperhatikan dalam proses pemberdayaan perempuan, yaitu welfare, access, participation, dan equality of control.

Pemberdayaan pendidikan (education empowerment) bagi masyarakat khususnya perempuan yaitu sebagai alternatif pendidikan formal yang bertujuan untuk mengembangkan potensi perempuan, dengan menekankan pada penguasaan pengetahuan dan keterampilan diri serta pengembangan sikap pribadi yang profesional (Sutisna, 2013).Pendidikan adalah instrumen yang layak dalam membawa perubahan positif dalam pola kehidupan orang (Ndu, 2002). Pendidikan menjadi proses sosial yang bertanggung jawab untuk mengembangkan dan memupuk berbagai kualitas fisik, intelektual, estetika dan moral serta nilai-nilai dalam diri seseorang (Lubem \& Sarah, 2018). Menciptakan akses ke pendidikan yang berkualitas memberikan kesempatan pada perempuan untuk memulai dan mengelola bisnis mereka tanpa bergantung pada suami mereka (Lockhead \& Verspoor, 1994).

Pemberdayaan ekonomi (economic empowerment) merupakan penguatan kepemilikan faktor-faktor produksi, penguatan penguasaan distribusi dan pemasaran, penguatan masyarakat untuk mendapatkan penghasilan yang memadai, dan penguatan masyarakat untuk memperoleh berbagai informasi mengenai pengetahuan dan keterampilan, yang harus dilakukan oleh masyarakat maupun pemangku kebijakan (Hutomo, 2000). Pemberdayaan ekonomi masyarakat dilakukan dalam rangka mempersiapkan pribadi masyarakat menjadi wirausaha. Tujuan pemberdayaan ekonomi perempuan adalah untuk meningkatkan status sosial ekonomi perempuan melalui penciptaan ekonomi melalui keterampilan teknis untuk membekali mereka dengan berbagai usaha ekonomi serta meningkatkan emansipasi wanita dari kemiskinan. Pemberdayaan ekonomi memungkinkan perempuan untuk menggunakan potensi dan energi mereka untuk menciptakan kekayaan dan menjadi mandiri secara ekonomi (Lubem \& Sarah, 2018).

\section{Entrepreneurial Self-Efficacy}

Seseorang yang memilih sebagai wirausaha sebagai pilihan mereka, memiliki persepsi tertentu mengenai tingkat kemenarikan karir berwirausaha (career attractiveness), tingkat kelayakan berwirausaha (feasibility) dan keyakinan atas diri sendiri (entrepreneurial self-efficacy) untuk memulai usaha (Farzier \& Niehm, 2008). Menurut Laura (2010), entrepreneurial self-efficacy adalah keyakinan seseorang sehingga dapat menguasai suatu situasi dan menghasilkan berbagai hasil yang bernilai positif dan bermanfaat.

\section{New Venture Creation}

Seorang entrepreneur harus melalui suatu proses untuk mendapatkanpemahaman, pengetahuan serta pengalaman dalam menjalankan kegiatan bisnisnya. Proses yang harus dilalui oleh seorang entrepreneur dengan memadukan atau mengkombinasikan peluang, sumberdaya serta organisasi tempat entrepreneur melakukan kegiatan bisnisnya atau organisasi bisnis yang dimilikinya (Supeni \& Sari, 2011). Proses untuk membuat suatu bisnis baru (creating a new venture) bukanlah merupakan suatu hal yang mudah, begitu banyak kendala yang harus dihadapi oleh seorang entrepreneur. Seorang entrepreneur harus melakukan identifikasi, evaluasi dan mengembangkan peluang tersebut dengan sebaik-baiknya (Arafah, 2010). New venture creation adalah menciptakan peluang bisnis baru dan mengambil resiko yang sudah diperhitungkan dengan menggunakan sumber daya yang terbatas (Timmons, 1999). 
Noormalita Primandaru. Pengaruh Educational dan Economic Empowerment terhadap New Venture Creation: Peran Moderasi Entrepreneurial Self-Efficacy

\section{Hubungan antar Variabel}

Proses pemberdayaan perempuan yang efektif dan berkelanjutan harus mencakup perluasan akses perempuan ke peluang pendidikan, akuisisi keterampilan dan posisi otoritas (Enemuo, 2001). Correia (2000) juga berpendapat bahwa memberikan pendidikan keuangan kepada perempuan akan menciptakan kesadaran akan kendali atas peluang dan pilihan finansial mereka serta penciptaan bisnis baru. Memampukan perempuan untuk mengembangkan keaksaraan dapat secara efektif berkontribusi terhadap kesehatan dan kesejahteraan keluarga mereka dan keluarga mereka serta dengan perluasan bagi komunitas mereka. Pratama (2013), Hendratni \&Ermalina (2013), dan Lubem \& Sarah (2018) dalam penelitiannya juga menyampaikan hal serupa.

\section{H1: Educational empowerment berpengaruh positif terhadap new venture creation.}

Pemberdayaan memungkinkan perempuan menggunakan potensi dan energinya untuk menciptakan kekayaan dan mandiri secara ekonomi. Perempuan harus memiliki akses dan kontrol atas penghasilan (Lubem \& Sarah, 2018). Melalui wirausaha dan kewirausahaan, perempuan mendapatkan kepercayaan diri, harga diri dan pengalaman pengambilan keputusan yang mengarah ke kontrol yang lebih besar atas kehidupan mereka di bidang sosial, ekonomi dan politik (Woldie \& Adersua, 2004). Menurut Okeke (1995), pemberdayaan ekonomi perempuan akan meningkatkan produktivitas perempuan dan dengan demikian meningkatkan Produk Nasional Bruto bangsa, serta diyakini bahwa sejumlah besar pendapatan perempuan dihabiskan untuk memberi makan dan merawat keluarga. Duflo (2012), Loh \& Dahesihsari (2013), dan Datta \& Sahu (2017)

\section{$\mathrm{H} 2$ : Economic empowerment berpengaruh positif terhadap new venture creation.}

Entrepreneurial self-efficacy yang dirasakan mengacu pada keyakinan pada kemampuan seseorang untuk memobilisasi motivasi, sumber daya kognitif, dan tindakan yang diperlukan untuk memenuhi tuntutan situasional yang diberikan (Wood \& Bandura, 1989). Chen et al. (1998) memperkirakan bahwa niat untuk menjadi pengusaha dengan memulai bisnis baru secara positif dipengaruhi oleh entrepreneurial self-efficacy yang pada gilirannya memfasilitasi niat individu untuk menciptakan usaha baru. Entrepreneurial self-efficacy dapat mempengaruhi pilihan mengenai aktivitas, usaha, dan pencapaian. Semakin kuat keyakinan seseorang memiliki, yang lebih besar dan lebih gigih adalah usahanya (Bandura, 1989). Seseorang yang menganggap dirinya sangat efektif memberikan upaya yang cukup, jika dilaksanakan dengan baik, dapat menghasilkan hasil yang sukses (Supeni \& Sari, 2011). Beberapa penelitiang yang mendukung penelitian Supeni \& Sari (2011) adalah Hmieleski \& Corbett (2008), Tang (2008) dan Lubem \& Sarah (2018).

H3: Entrepreneurial self-efficacy memoderasi educational empowerment dan economic empowerment terhadap new venture creation.

\section{METODE PENELITIAN}

Desain penelitian yang digunakan adalah confirmatory riset dengan tujuan utama untuk menguji pengaruh variabel educational empowerment, economic empowerment, entrepreneurial self-efficacy, dan new venture creation. Setting yang digunakan adalah field research. Instrumen dalam penelitian ini mengadopsi instrumen penelitian yang telah dikembangkan penelitian sebelumnya di mana semua jawaban dari pertanyaan akan diukur dalam lima skor dengan menggunakan skala ordinal 5 poin Likert, mulai dari sangat setuju (poin 5) sampai sangat tidak setuju (poin 1). Jumlah pernyataan di dalam kuesioner sebanyak 40 butir, terdiri dari 10 butir pernyataan mengenai educational empowerment, 10 butir pernyataan terkait economic empowerment, 10 butir pernyataan terkait new venture creation dan 10 butir pernyataan terkait entrepreneurial self-efficacy. Populasi dalam penelitian ini adalah para perempuan yang berdomisili di Pesisir Bantul. Pengambilan sampel yang digunakan adalah nonprobability sampling tipe purposive sampling dengan kriteria sampel yang ditentukan dalam penelitian ini adalah perempuan atau ibu-ibu yang tergabung dalam PKK. Pada penelitian ini, data yang diperlukan dikumpulkan melalui penyebaran kuesioner kepada responden dengan menggunakan daftar pertanyaan yang sudah dibuat sebelumnya, bersifat terbuka dan dibatasi 
sesuai dengan cakupan penelitian. Kuesioner diberikan kepada perempuan yang tergabung pada kelompok PKK di Pesisir Bantul. Dari 145 kuesioner yang dibagikan, sebanyak 138 responden mengembalikan kuesioner (response rate sebesar 95\%). Jumlah kuesioner yang tidak dapat diolah sebanyak 8 kuesioner yang tidak mengisi keterangan yang diperlukan. Kuesioner yang dapat diolah berjumlah 127 responden. Tabel 1 menunjukkan rincian hasil penyebaran kuesioner. Data dianalisis dengan Partial Least Square dengan software WarpPLS 7.

Tabel 1

HASIL PENYEBARAN KUESIONER

\begin{tabular}{lll}
\hline \multicolumn{1}{c}{ Keterangan } & \multicolumn{1}{c}{ Jumlah } & Persentase (\%) \\
\hline Kuesioner yang didistribusikan & 145 & 100 \\
Kuesioner yang dikembalikan & 138 & 97 \\
Kuesioner yang tidak dapat diolah & 11 & 7 \\
Kuesioer yang dapat diolah & 127 & 92 \\
\hline
\end{tabular}

\section{HASIL DAN PEMBAHASAN}

\section{Karakteristik Responden}

Tabel 2 menunjukkan bahwa 95\% wanita di Pesisir Bantul berprofesi sebagai entrepreneur, dan sisanya bekerja sebagai karyawan toko. Selanjutnya, jumlah wanita di Pesisir Bantul didominasi oleh usia 25-35 tahun yaitu sebesar 48\% dan lulusan terbanyak adalah lulusan dari SMA/ sederajat.

\section{Tabel 2}

\section{KARAKTERISTIK RESPONDEN}

\begin{tabular}{|c|c|c|}
\hline \multicolumn{2}{|c|}{ Karakteristik Responden } & Prosentase \\
\hline Profesi & Entrepreneur & $95 \%$ \\
\hline & Karyawan & $15 \%$ \\
\hline Usia & $<25$ tahun & $29 \%$ \\
\hline & $25-35$ tahun & $48 \%$ \\
\hline & $36-40$ tahun & $15 \%$ \\
\hline & $>40$ tahun & $9 \%$ \\
\hline Pendidikan & SD & $6 \%$ \\
\hline & SMP/Sederajat & $24 \%$ \\
\hline & SMA/Sederajat & $50 \%$ \\
\hline & Akademi (D1-D3) & $11 \%$ \\
\hline & Sarjana (S1) & $10 \%$ \\
\hline
\end{tabular}

Sumber: Data diolah (2021)

\section{Hasil Uji Validitas dan Reliabilitas}

Dasar yang digunakan dalam uji reliabilitas adalah nilai Composite reliability coefficients dan Cronbach's alpha coefficients di atas 0,5. Hasil pada tabel 3 menunjukkan bahwa instrumen kuesioner dalam penelitian ini telah memenuhi ketentuan uji reliabilitas. Uji validitas ini menunjukkan kesesuaian setiap indikator dengan teori-teori yang digunakan untuk mendefinisikan suatu konstruk (Hartono, 2008). Kriteria uji validasi adalah dengan menggunakan kriteria factor loadings (crossloadings factor). Ukuran untuk indikator reflektif dikatakan valid, jika nilai cross loading $\geq 0,7$ dengan konstruk yang diukur. Namun menurut Chin (1998), untuk penelitian tahap awal dari pengembangan skala pengukuran nilai cross loading berkisar 0,5 sampai 0,6 dianggap cukup memadai. Nilai AVE konstruk seharusnya lebih tinggi dibandingkan dengan korelasi antar variabel laten (Solihin dan Ratmono, 2013). Hasil perhitungan WarpPLS 7 pada tabel 3 menunjukkan bahwa masing-masing nilai pada cross-loadings factor telah mencapai nilai diatas 0,5 dengan nilai $\mathrm{P}<0,001$. Dengan demikian kriteria uji validitas konvergen telah terpenuhi. 
Noormalita Primandaru. Pengaruh Educational dan Economic Empowerment terhadap New Venture Creation: Peran Moderasi Entrepreneurial Self-Efficacy

Tabel 3

HASIL UJI RELIABILITAS DAN VALIDITAS

\begin{tabular}{|l|l|l|l|l|l|l|l|}
\hline Variabel & Indikator & Factor Loading & P Value & AVE & CR & Validitas & Reliabilitas \\
\hline Edu & & & & 0,670 & 0,836 & valid & reliabel \\
\hline & Ed2 & 0,585 & $<0.001$ & & & valid & reliabel \\
\hline & Ed3 & 0,809 & $<0.001$ & & & valid & reliabel \\
\hline & Ed4 & 0,822 & $<0.001$ & & & valid & reliabel \\
\hline & Ed5 & 0,845 & $<0.001$ & & & valid & reliabel \\
\hline Eco & & & & 0,644 & 0,756 & valid & reliabel \\
\hline & Eco1 & 0,694 & $<0.001$ & & & valid & reliabel \\
\hline & Eco2 & 0,648 & $<0.001$ & & & valid & reliabel \\
\hline & Eco3 & 0,540 & $<0.001$ & & & valid & reliabel \\
\hline & Eco4 & 0,547 & $<0.001$ & & & valid & reliabel \\
\hline Self & & & & 0,605 & 0,772 & valid & reliabel \\
\hline & Se1 & 0,669 & $<0.001$ & & & valid & reliabel \\
\hline & Se2 & 0,677 & $<0.001$ & & & valid & reliabel \\
\hline & Se3 & 0,675 & $<0.001$ & & & valid & reliabel \\
\hline Ncv & & & & 0,612 & 0,887 & valid & reliabel \\
\hline & Nvc1 & 0,800 & $<0.001$ & & & valid & reliabel \\
\hline & Nvc2 & 0,820 & $<0.001$ & & & valid & reliabel \\
\hline & Nvc3 & 0,732 & $<0.001$ & & & valid & reliabel \\
\hline & Nvc4 & 0,737 & $<0.001$ & & & valid & reliabel \\
\hline
\end{tabular}

Sumber: Data diolah (2021)

\section{Uji Model Penelitian}

Uji model penelitian dilakukan untuk melihat kesesuaian model yang dibangun dalam penelitian. Model penelitian yang baik akan dapat menggambarkan kesesuaian hubungan antara variabel dalam penelitian. Penggunaan WarpPLS 7 telah memberikan hasil perhitungan yang menunjukkan kriteria yang digunakan untuk menilai apakah model telah sesuai.



\section{Gambar 1. HASIL GOODNESS OF FIT VARIABEL DENGAN WARPPLS 7.}

Gambar 1 menjelaskan bahwa APC memiliki indeks sebesar 0,282 dengan nilai p-value $<0,001$. Sedangkan ARS memiliki indeks sebesar 0,295 dengan p-value <0,001. Berdasarkan kriteria, APC sudah memenuhi kriteria karena memiliki nilai $\mathrm{p}<0,001$. Begitu pula dengan nilai $\mathrm{p}$-value dari ARS yaitu $\mathrm{p}<0.001<0,05$. Nilai AVIF yang harus $<5$ sudah terpenuhi karena berdasarkan data tersebut AVIF nilainya 1,263. Dengan demikian, maka model penelitian dapat diterima.

\section{Hasil Pengujian Hipotesis}

Pengujian hipotesis ini juga dimaksudkan untuk membuktikan kebenaran dugaan penelitian atau hipotesis. Hasil korelasi antar konstruk diukur dengan melihat path coefficients dan tingkat signifikansinya yang kemudian dibandingkan dengan hipotesis penelitian. Tingkat signifikansi yang dipakai dalam penelitian ini adalah sebesar $5 \%$. 


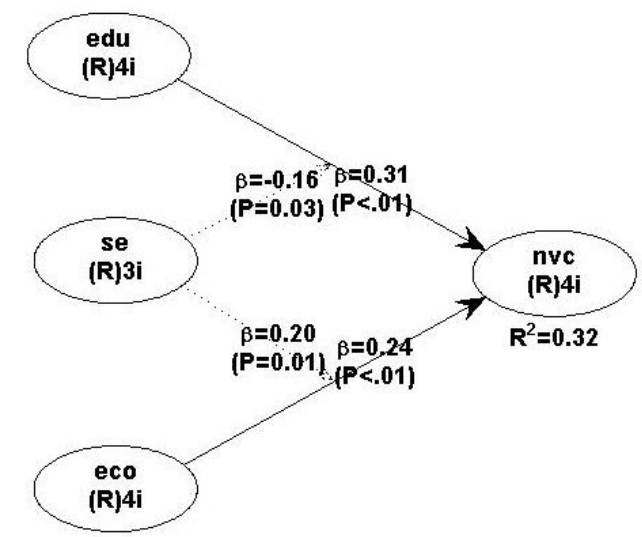

\section{Gambar 2. HASIL PENGUJIAN VARIABEL MENGGUNAKAN WARPPLS 7.0}

Hasil analisis menggunakan alat uji WarpPLS 7.0 yang ditunjukkan pada Gambar 2 yaitu sebagai berikut. Hipotesis pertama dalam penelitian ini adalah pengaruh educational empowerment pada new venture creation perempuan di Pesisir Bantul. Hasil penelitian menunjukkan bahwa nilai koefisien = 0,31 ( $p$ value $<0,01$ ). Hal tersebut menunjukkan bahwa variabel entrepreneurial education berpengaruh terhadap new venture creation perempuan di Pesisir Bantul. Hipotesis kedua dalam penelitian ini adalah pengaruh economic empowerment terhadap new venture creation pada perempuan di Pesisir Bantul. Hasil penelitian menunjukkan bahwa nilai koefisien $=0,24$ ( $p$ value < $0,01)$. Hal tersebut menunjukkan bahwa variabel economic empowerment berpengaruh terhadap terhadap new venture creation pada perempuan di Pesisir Bantul. Hipotesis ketiga dalam penelitian ini adalah entrepreneurial self-efficacy memoderasi educational empowerment dan economic empowerment terhadap new venture creation perempuan di Pesisir Bantul. Hasil penelitian menunjukkan bahwa nilai moderasi koefisien variabel entrepreneurial self-efficacy pada educational empowerment terhadap new venture creation pada perempuan di Pesisir Bantul adalah - 0,16 (p-value : $0,03)$ dan nilai moderasi koefisien variabel entrepreneurial self-efficacy pada economic empowerment terhadap new venture creation pada perempuan di Pesisir Bantul adalah 0,20 ( $p$-value : 0,01) Hal tersebut menunjukkan bahwa variabel entrepreneurial self-efficacy memoderasi variabel educational empowerment, economic empowerment, technological advancement terhadap new venture creation perempuan di Pesisir Bantul.

\section{Pembahasan}

Hipotesis satu menyatakan bahwa educational empowerment berpengaruh terhadap new venture creation perempuan di Pesisir Bantul. Sejalan dengan penelitian yang dilakukan Leon et al., (2007) menyatakan bahwa educational empowerment dapat meningkatkan pengetahuan seseorang tentang manajemen bisnis dan meningkatkan karakterisitik-karakteristik pribadi seorang wirausahawan. Kementerian Pemberdayaan Perempuan dan Perlindungan Anak (2012) juga menyatakan bahwa masyarakat yang berpendidikan, memiliki semangat dan optimis terhadap masa depannya. Disamping itu mereka umumnya menyelesaikan sendiri masalah-masalah yang dihadapinya. Claros \& Zahidi, (2005) menyatakan bahwa pendidikan, pekerjaan, dan kepemilikan hak perempuan memberikan pengaruh yang kuat untuk meningkatkan kemampuan mereka untuk menguasai lingkungan mereka dan memberikan kontribusi bagi pembangunan ekonomi. Pendidikan yang dimaksud dalam penelitian ini adalah pelatihan dari beberapa instansi swasta atau pemerintah. Hasil penelitian ini didukung oleh penelitian terdahulu, yaitu Correia (2000), Pratama (2013), Hendratni \&Ermalina (2013), dan Lubem \& Sarah (2018).

Hipotesis dua menyatakan bahwa economic empowerment berpengaruh terhadap new venture creation pada perempuan di Pesisir Bantul. Teori dasarnya adalah bahwa memberdayakan perempuan dengan menempatkan modal di tangan mereka dapat memungkinkan mereka untuk mendapatkan penghasilan mandiri dan berkontribusi secara finansial kepada rumah tangga dan komunitas mereka (Koenig et al., 2003). Pemberdayaan ekonomi ini diharapkan menghasilkan peningkatan harga diri, rasa hormat, dan 
bentuk-bentuk pemberdayaan lain bagi penerima manfaat perempuan dengan membuka usaha. Microfinance membantu dengan pinjaman kecilnya untuk memberdayakan perempuan, Microfinance bersumsi bahwa setiap manusia memiliki potensi kewirausahaan, tetapi hanya kurang memiliki akses ke kredit (Torry et al., 2014). Hasil penelitian ini didukung oleh penelitian terdahulu Duflo (2012), Loh \& Dahesihsari (2013), Datta \& Sahu (2017), dan Lubem \& Sarah (2018).

Hipotesis ketiga menyatakan bahwa entrepreneurial self-efficacy memoderasi educational empowerment dan economic empowerment terhadap new venture creation perempuan di Pesisir Bantul. Hal ini sejalan dengan penelitian yang dilakukan oleh Lubem., et al (2018) terdapat pengaruh moderasi entrepreneurial self-efficacy pada hubungan antara educational empowerment dan economic empowerment terhadap penciptaan usaha baru di Negara Bagian Benue. Schunk (1995) yang menyatakan entrepreneurial self-efficacy dapat membantu memprediksi motivasi dan kinerja wirausaha. Zimmerman., et al. (1992) menegaskan bahwa entrepreneurial self-efficacy dirasakan mampu secara langsung dan tidak memengaruhi tujuan yang ditetapkan sendiri, tingkat tujuan yang ditetapkan, dan memunculkan kegigihan individu ketika kesulitan ditemukan. Hasil penelitian ini didukung oleh penelitian terdahulu yaitu Supeni \& Sari (2011), Hmieleski \& Corbett (2008), Tang (2008), dan Lubem \& Sarah (2018).

Implikasi manajerial dalam penelitian ini adalah dukungan dari pemerintah, perguruan tinggi, lembaga swasta dan masyarakat tentang peningkatan strategi kualitas SDM perempuan, seperti wawasan, pengetahuan, dan pelatihan ketrampilan, peningkatan dan penumbuh kembangan kegiatan ekonomi produktif, peningkatan terhadap akses sumber daya ekonomi, seperti modal dan teknologi informasi, memperkuat dan mengembangkan kelembagaan ekonomi mikro, serta mengembangkan kemitraan usaha yang saling menguntungkan. Kegiatan-kegiatan tersebut dapat berupa: Perguruan tinggi melalui Dharma Pengabdian Pada Masyarakat dapat memberikan pelatihan untuk peningkatan pengetahuan dan keterampilan perempuan muda serta memperkuat sifat entrepreneurial self-efficacy sebagai bekal untuk membuka dan mengembangkan usaha; dan pemerintah, lembaga swasta, dan lembaga keuangan mikro harus memberikan perhatian serius pada pengembangan dan pelatihan kewirausahaan dengan menempatkan prioritasnya secara tepat dan mengeluarkan dana untuk pengembangan usaha. Dengan beberapa kegiatan tersebut diharapkan dapat meningkatkan potensi kaum perempuan dalam melaksanakan kegiatan perekonomian secara mandiri sekaligus meningkatkan kemakmuran seluruh masyarakat, khususnya kawasan pesisir.

\section{KESIMPULAN}

Berdasarkan hasil dan pembahasan pada bagian sebelumnya, maka dapat disimpulkan bahwa variabel educational empowerement, dan economic empowerment berpengaruh terhadap new venture creation perempuan di Pesisir Bantul dan variabel entrepreneurial self-efficacy memoderasi terhadap educational empowerement dan economic empowerment pada terciptanya new venture creation. Penelitian ini terbatas dilakukan terhadap perempuan atau ibu-ibu yang tergabung dalam PKK di pesisir Bantul, Yogyakarta. Penelitian selanjutnya diharapkan dapat menggunakan variabel berbeda yang berkaitan dengan faktor-faktor yang mempengaruhi new venture creation, seperti pengalaman, risk tolerance dan penggunaan media sosial dan teknologi, ataupun menggunakan metode analisis lainnya sehingga hasil penelitian terkait new venture creation lebih bervariasi dan lebih akurat.

\section{DAFTAR PUSTAKA}

Ahlin, B., Drnovsek, M., \& Hisrich, D., R. (2013). Entrepreneurs' Creativity And Firm Innovation: The Moderating Role Of Entrepreneurial Self-Efficacy. Small Bus Econ. 43:101-117

Arafah, Willy. (2010). Esensi Lingkungan Bisnis \& Entrepreneurship. Jakarta: Universitas Trisakti

Bandura, A., \& Wood, R.E. (1989). Effect Of Perceived Controllability And Performance Standards On Self Regulation Of Complex Decision Making. Journal Of Personality And Social Psychology, 56, 805-814. 
Bandura, A. (1989). Human Agency in Social Cognitive Theory. The American Psychologist, 44(9), $1175-1184$.

Correia, A. (2000). Strategies To Expand Battered Women's Economic Opportunities: Building Comprehensive Solution To Domestic Violence. Hinesburg: National Resources Centre On Domestic Violence.

Datta, Srimoyee., \& Sahu, Tarak Nath. (2017). An Empirical Study on the Impact of Microfinance on Women Empowerment: Evidence from West Bengal. Indian Journal of Commerce and Management Studies. Vol. 08, No 3. 53-62

Duflo, E. (2012). Women Empowerment and Economic Development. Journal Of Economic Literature. Vol. 50, No. 4. 1051-1079.

Enemuo, F. C. (2001). Political Participation And The Economic Empowerment Of Nigerian Women: Imperatives And Prospects. In Obi C. I. (Ed), Women's Political Participation Through Economic Empowerment. Lagos: O.V.C. Nigeria Limited.

Gregory J. Feist. (2011). Teori Kepribadian. Jakarta: Salemba Humanika.

Hendratni, Tyahya Whisnu., \& Ermalina. (2013). Womanpreneur, Peranan dan Kendalanya Dalam Kegiatan Dunia Wirausaha. Jurnal Liquidity. Vol. 2 (2): 170-178.

Hmieleski, K. M., \& Corbett, A. C. (2008). The Contrasting Interaction Effects Of Improvisational Behaviour With Entrepreneurial Self-Efficacy On New Venture Performance And Entrepreneur Work Satisfaction. Journal of Business Venturing. Vol. 23, No. 4. 482-496.

Laura. 2010. Psikologi Umum. Jakarta: Salemba Humanika

Loh, J. M. I \& Dahesihsari, R. (2013). Resilience And Economic Empowerment: A Qualitative Investigation Of Entrepreneurial Indonesian Women. Journal of Enterprising Culture, Vol. 2 (1): 107-121.

Lubem, A. E., \& Sarah, D. H. (2018). Moderating Effect Of Self-Efficacy On The Relationship Between Women Empowerment And New Venture Creation In Benue State Nigeria. International Journal Of Information, Business and Management, Vol 10, No.2, 1-18

Okeke. (1995). Woman Empowerment and Rural Development. Rural Development In Nigeria: Concepts, Processes and Prospects. Enugu. Auto-century pp.152-163.

Pratama, Crisvi. (2013). Faktor-faktor yang Mempengaruhi Keberhasilan Pemberdayaan Perempuan Desa Joho di Lereng Gunung Wilis. Kebijakan dan Manajemen Publik. Vol 1, No.1. 12-19.

Sekaran, Uma. 2006. Metode Penelitian Untuk Bisnis 1. (4th Ed). Jakarta: Salemba Empat

Supeni, R.E., \& Sari, M.I. (2011). Upaya Pemberdayaan Ekonomi Perempuan Melalui Pengembangan Manajemen Usaha Kecil (Studi Diskriptif Pada Kegiatan Usaha Kecil Ibu-Ibu Desa Wirolegi Kabupaten Jember, Dampingan Pusat Studi Wanita Um Jember). Seminar Nasional Ilmu Ekonomi Terapan . Fakultas Ekonomi Unimus 2011. 101-111.

Tang, J. (2008). Environmental Munificence For Entrepreneurs: Entrepreneurial Alertness And Commitment. International Journal of Entrepreneurial Behaviour and Research. Vol 14, No 3. 128-151.

Timmons, J.A. (1999), New Venture Creation: A Guide To Entrepreneurship For 21st Century, Irwin, 
Noormalita Primandaru. Pengaruh Educational dan Economic Empowerment terhadap New Venture Creation: Peran Moderasi Entrepreneurial Self-Efficacy

Homewood, Il.

Utari, Tri \& Dewi, P. M. (2014). Pengaruh Modal, Tingkat Pendidikan Dan Teknologi Terhadap Pendapatan Usaha Mikro Kecil Dan Menengah (UMKM) Di Kawasan Imam Bonjol Denpasar Barat. E- Jurnal Ekonomi Pembangunan Universitas Udayana. Vol. 3, No. 12. 576585

Woldie, A. And Adersua, A. (2004). Female Entrepreneurs In A Transitional Economy: Business Women In Nigeria. International Journal Of Social Economist, 31(12), 78-90

Zahra, S., Wright, M., 2011. Entrepreneurship's Next Act. Academy Of Management Perspectives 25, 67-83 